\title{
BRYOERYTHROPHYLLUM FERRUGINASCENS (STIRT.) GIAC. (POTTIACEAE, MUSCI) IN RUSSIA \\ BRYOERYTHROPHYLLUM FERRUGINASCENS (STIRT.) GIAC. (POTTIACEAE, MUSCI) В РОССИИ
}

\author{
Elena A. Ignatova ${ }^{1} \&$ Michael S. IGNATOV ${ }^{2}$ \\ ЕЛЕНА А. ИГНАТОВА ${ }^{1}$ и МИХАИЛ С. ИГНАТОВ ${ }^{2}$
}

Abstract

Bryoerythrophyllum ferruginascens (Stirt.) Giac. was known until recently in Russia as a rare Arctic species. In last years it was found also in Khabarovsk Territory, Sakha/ Yakutiya and Altai Territory. Probably, this species is not rare in Siberia in areas with calcareous soils. Description and illustration are provided.

Резюме

Bryoerythrophyllum ferruginascens (Stirt.) Giac. до недавнего времени был известен в России только как редкий арктический вид. В последние годы он был обнаружен также в Хабаровском крае, Саха (Якутии) и Алтайском крае. По-видимому, этот вид не редок в Сибири в районах с карбонатными почвами. Приводятся описание и иллюстрации.

Bryoerythrophyllum ferruginascens (Stirt.) Giac. has been originally described from Britain (Braithwaite, 1887; first cited collection of 1865), as a variety of Barbula rubella var.ruberrima Ferg.Later it was found locally frequent in northern part of Britain, as well as in Ireland (Blockeel \& Long, 1998), and other oceanic countries of North Western Europe, especially Norway and Iceland (Söderström, 1996). Also in NW Europe it is known from Sweden (mostly North, rare in Smaland and Aland), Finland (extreme North), Faroes (Söderström, 1996).

In Central Europe B. ferruginascens is very rare. Until recently it was known only from South Germany,where it was found in 1904 and described as Barbula botelligera Mönk.(Murr,1914) and Tirol,Austria (Mönkemayer,1927; Podpera,1954).Later this species was discovered in Poland (Szafran, 1957), Spain (Casas Sicart, 1981),Czechia (Vana,1997),Belgeand Switzerland (Arts,1989),France(Vadam,1991).In Germany in recent past it was found several times (Grundmann, 1993 [1992]; Risse,1991; Kaiser,1991),but it is still very rare and was included in the Red List of the country (Ludwig \& al., 1996), as well as in Red List of bryophytes of Switzerland (Urmi, 1991). In Japan this species is known only from Honshu (Iwatsuki,1991 as B. rubrum var.minus), in China - from 7 provinces, mostly in Central China, but also Yunnan (Redfearn \& al.,1996).

In North America B. ferruginascens is known in Alaska,Greenland,mountains of theWest,Appalachians, and southwards to volcanic zone of central Mexico (Zander,1978; Eckel,1990).

Also this species was reported from Papua New Guinea (Norris, Koponen, 1989), as a widespread species in different habitats, including tropical rain forest; however the gemmae mentioned for New Guinean species are quite different from those of $B$. ferruginascens from northern regions both in shape and position (axillary vs. rhizoidal correspondingly). We have seen several collection from Huon Peninsula in $\mathrm{H}$, and found that they were correctly described by Norris \& Koponen (1. c.), but doubtfully belong to $B$. ferruginascens.

In Russia B. ferruginascens was first reported by Arnell (1913) from Lower Lena River, but Savicz-Ljubitskaya \& Smirnova (1970) revised this specimen and reidentified it. The next report of this species from Russia was done by L. Savicz (1936) from Franz-Josef Land, with a brief descriptions; however in LE this specimen is absent. The first herbarium specimen of $B$. ferruginascens from Russia is the collection of Afo-

1 - Moscow State University, Biological Faculty, Moscow 119899 Russia - Россия 119899 Москва, Московский государственный университ, Биологический факультет

2 - Main Botanical Garden of Russian Academy of Sciences, Botanicheskaya 4, Moscow 127276 Russia - Россия 127276 Москва, Ботаническая 4, Главный ботанический сад Российской Академии Наук 
nina from Vrangel Island in 1985 (LE); seeAfonina \& Czernyadjeva (1995). Plants were collected in wet shrubby-mossy tundra, along temporary stream bed.

In recent years $B$. ferruginascens was found in Siberia in number of places:

1) Khabarovsk Territory, Upper Bureya River, at 530-700 m elev., in two localities, on open places of banks of Bureya and Levaya Bureya Rivers, on gravely bars of river and rock outcrops, collected by Ignatov and Tan (Ignatov $\&$ al., 2000).

2) Republic Sakha/Yakutiya, eastern part, Ust-Maya District, at 370-600 m elev., in two localities, on sandy river bar, along old road in forest, on rock outcrop, and on Populus trunk covered by alluvium in flood valley, collected by Ignatov and Ivanova (Ignatov \& al., 2001).

3) Altai Mts.:

a) $50^{\circ} 24^{\prime} \mathrm{N}-89^{\circ} 20^{\prime} \mathrm{E}, 2400 \mathrm{~m}$, Bogoyash Creek, S-faced rock outcrop, Ignatov 27.VII.1993 (MHA).

b) $50^{\circ} 32^{\prime} \mathrm{N}-89^{\circ} 05^{\prime} \mathrm{E}, 1900 \mathrm{~m}$, Karakem Creek, rocks of S-faced slope, Ignatov 24.VI.1989 (MHA).

c) $51^{\circ} 24^{\prime} \mathrm{N}-86^{\circ} 00^{\prime} \mathrm{E}, 400 \mathrm{~m}$, Chemal, temporarily flooded part of the valley of Katun River, on sandy banks and rocks covered by alluvium, Ignatova 2.VIII.2000 (MW).

d) $50^{\circ} 29^{\prime} \mathrm{N}-86^{\circ} 35^{\prime} \mathrm{E}, 600 \mathrm{~m}$, Malyj Yaloman, temporarily flooded part of the valley of $\mathrm{Ka}$ tun River, on sandy banks and rocks covered by alluvium, mostly under Populus trees, Ignatova 4.VIII.2000 (MW).

This species is probably not very rare in Siberia in areas with calcareous substrates, judging from that it was found in most of extensively collected places. Note however, that considerable part of Siberia has more acid soils / rocks comparatively with above listed places. The fact, that this species was not recognized before can be explained by just not enough attention to Pottiaceae of Siberia, which need much further studies.

Bryoerythrophyllum ferruginascens (Stirt.) Giac., Atti Ist. Bot. Univ. Lab. Critt. Pavia ser. 5, 4: 210. 1947. - Barbula ferruginascens Stirt., Ann. Scot. Nat. Hist. 9(35): 176. 1900.

Barbula botelligera Moenk. in Murr, Allg. Bot. Zeitschr. 20: 24. 1914.

Barbula rubella var.ruberrima Ferg.in Braithw., Brit. Moss. Fl. 1: 261. 1887.

Bryoerythrophyllum rubrum var. minus K. Saito, J. Hattori Bot. Lab., 39: 476, fig. 40. 1975. (synonimized by Sollman, 1983).
Plants in loose to moderately dense tufts, on sandy substrates, partly bured into sand, yellowish-green inside, red-brown in exposed parts, or red-brown troughout. Stem 7-17 mm long, evenly foliate with upper leaves slightly larger,simpleor rarely branched or with subperichaetial innovations, in transverse cross section rounded-polygonal, central strand well-developed, cortex of 2-3 layers of thick-walled cells, hyalodermis absent. Axillary hairs 7-9-celled, to $190 \mu \mathrm{m}$ long, hyaline throughout, cells firm-walled, upper cell to $38 \mu \mathrm{m}$ long, $12.5 \mu \mathrm{m}$ wide. Leaves appressed-incurved to weakly twisted when dry,erect-spreading when wet,1.0-1.3x 0.4-0.5 mm, ovate-lanceolate, rather abruptly contracted above broad (in upper leaves - sheating) base, gradually acuminate, and in leaf tip with 1-3-celled apiculus, composed of smooth or slightly papillose cells, nondecurrent,obtusely keeled in upper part; margin entire, plane in upper part, distinctly recurved at base; costa percurrent, ca. $60 \mu \mathrm{m}$ wide at base, superficial cells on dorsal and ventral surfaces above short-rectangular to subquadrate,papillose,below rectangular,smooth; costa in transeverse section hemisphaeric, with 2-4 guide cells in onerow,2 stereid bands (ventral weaker),dorsal and ventral epidermis differentiated,ventral 4-celled wide; laminal cells not bulging in transverse section, in upper leaf subquadrate, 9-10 $\mu \mathrm{m}$, densely papillose, opaque, papillae 3(-4) per cell, low, bifid, looking c-shaped, cell walls evenly thickened; basal cells short rectangular, to $25 \mu \mathrm{m}$ long, $12-13 \mu \mathrm{m}$ wide, slightly papillose to smooth, hyaline or yellowish. Dioicous, sporophytes (very young + very old, partly decomposed) found in only one collection from Khabarovsk Territory. Perichaetial leaves to $2 \mathrm{~mm}$ long, sheating base to $1 \mathrm{~mm}$ long, costa percurrent. Seta 5-6 mm long, red-brown; urn ca. $1.0 \mathrm{~mm}$ long,elliptic, brown,smooth,operculum ca. 0.5 mm long. Calyptra cucullate. Rhizoidal gemmae usually present, more numerous on rocky substrates, red-brown, ovoid to irregular in shape, sometimes branching, 50-115(-185) x 30-70(-110) $\mu \mathrm{m}$, multicellular, opaque. $\mathrm{KOH}$ reaction red.

The above description is based on collections from Asian Russia. Savich (1936) described plants from Franz Josef Land as taller,to $5 \mathrm{~cm}$ high and having perichaetial leaves with excurrent costa.

Zander (1978) described sporophytes bigger in all parts: seta 7-8 mm long; urn 2.2-2.5 $\mathrm{mm}$ long, operculum 0.5-0.9 mm long; stomata small; annulus of 1-2 rows of vesiculate cells, deciduous, peristome absent or rudimentary, teeth to $25 \mu \mathrm{m}$ long, straight, yellow, spiculose, 


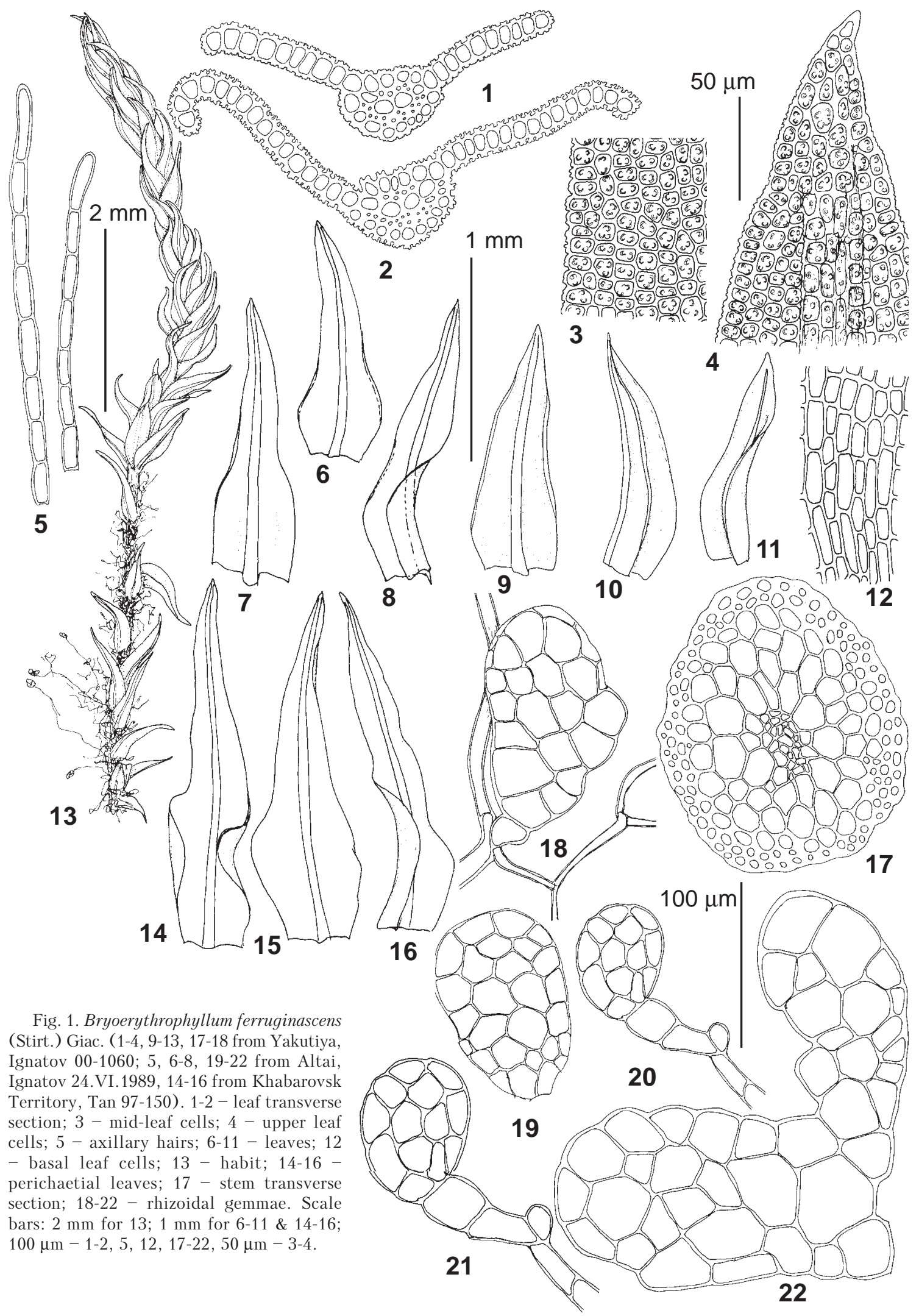


without basal membrane; spores $12-15 \mu \mathrm{m}$, slightly papillose.

Bryoerythrophyllum ferruginascens differs from widespread $B$. recurvirostrum (Hedw.) Chen in smaller plants,shorter acumen,margin recurved only near base (vs. nearly to the apex), mar- gin entire (vs. with few teeth near apex). The sheating base of perichaetial leaves is a peculiar feature in $B$. ferruginascens, but they present not in all collections; however in sterile state this species usually has rhizoid gemmae, allowing its easy recognition.

\section{LITERATURE CiTED}

AFONINA,O.M.\& I.V.CZERNYADJEVA 1995. Mosses of the Russian Arctic: check-list and bibliography.- Arctoa 5: 99-142.

ARNELL,H.W.1913.Zur Mooosflora des Lena-Tales.- Arkiv Bot. 13(2): 1-94.

ARTS,T.1989.Bryoerythrophyllum ferruginascens (Stirt.) Giac. (Pottiaceae, Bryales) nieuw voor de Belgische en Zwitserse mosflora. - Bull. Soc. Bot. Belg. 122: 151-156.

BLOCKEEL,T.C.\& D.C.LONG 1998.A check-list and census catalogue of British and Irish Bryophytes.- BBS,Cardiff. 208.

BRAITHWAITE,R.1887. The British moss flora.Vol.1.Acrocarpous mosses. - London, Published by the author: 1-315.

CASAS SICART, C. 1981. The mosses of Spain. An annotated check-list. - Treb. Inst. Bot. Barcelona 7: 1-58.

ECKEL, P. M. 1990 Bryoerythrophyllum ferruginascens (Musci: Pottiaceae) in eastern North America. Bryologist 93: 208-210.

GRUNDMANN, M. 1993 [1992]. Bryoerythrophyllum ferruginascens in Teutoburger Wald. - Bryologische Rundbriefe 12: 3.

IGNATOV, M. S., B. C. TAN, Z. IWATSUKI \& E. A. IGNATOVA 2000. Moss flora of the Upper Bureya River (Russian Far East). - J. Hattori Bot. Lab. \& : 147-178.

IGNATOV, M. S., E. I. IVANOVA, E. A. IGNATOVA \& K. K. KRIVOSHAPKIN 2001. On the moss flora of UstMaya District (Republic Sakha/Yakutia, East Siberia). - Arctoa 10: 165-184.

IWATSUKI, Z. 1991. Catalog of the mosses of Japan. Nichinan, Hattori Bot. Lab. $182 \mathrm{pp}$.

KAISER, B. 1991. Bryoerythrophyllum ferruginascens (Stirt.) Giac. Erstfund in Nordbayern. - Bryologische Rundbriefe 7: 5.

LUDWIG,G., R.DÜLL,G.PHILIPPI,M.AHRENS,S.CASPARI,M. KOPERSKI,S.LÜTT,F.SCHULZ \& G.SCHWAB 1996.RoteListe der Moose (Anthocerophytaet Bryophyta) Deutschlands. - In: Ludwig, G. \& Schnittler, M.(Bearb.): RoteListeder gefahrdeten Pflanzen DeutschlandsHiltrup (Landweritschaftszerl.) Schriftemreihe vegetationsk. 28: 189-306.

MÖNKEMAYER,W.1927.Die Laubmoose Europas.Andreales - Bryales. - In: Rabenhorst, G. L.: Kryptogamenflora von Deutschland,Oesterreich und der Schweiz. Bd. 4. - Leipzig, Geest \& Portig. 960 s.

MURR,J.1914.Zur Moosflora von Tirol und Vorarlberg.- Allg. Bot. Z. Syst. (Karlsruhe) 20: 24-25.
NORRIS,D.H.\& T.KOPONEN 1989. Bryophyteflora of the Huon Peninsula, Papua New Guinea. XXVIII. Pottiaceae (Musci). - Acta Bot. Fennica 137: 81-138.

PODPERA, J. 1954. Conspectus Muscorum Europaeorum. Praha,Czeskoslov. Akad. Ved. 699 pp.

REDFEARN,P.L.,B.C.TAN \& S.HE 1996.A newly updated and annotated checklist of Chinese mosses. - J. Hattori Bot. Lab. 79: 163-357.

RISSE, S. 1991. Bryoerythrophyllum ferruginascens (Stirt.) Giac. in Deutschland, mit Hinweisen zur Bestimmung der Art. Bryologische Rundbriefe 5: 1-3.

[SAVICZ,L.I.] САВИЧ,Л.И.1936.Мхи архипелага ФранцаИосифа,Северной земли и о.Визе,собранные В.П.Савичем во время полярной экспедиции 1930 г.на ледоколе "Г. Седов".- [Themosses of Franz Josef Archi pelago,Severnaya Zemlya and Wise Island collected by V.P.Savicz during polar expedition in 1930 on theice-breaker "G.Sedov"] Труды бот. ин-та АН СССР,сер. 2,Споровые растения [Trudy Bot. Inst. Akad. Nauk SSSR,ser. 2,Sporovye Rasteniya] 3: 505-578.

[SAVICZ-LYUBITSKAYA,L.I.\& Z.N.SMIRNOVA] CAВИЧЛЮБИЦКАЯ, Л.И., З.Н. СМИРНОВА 1970. Определитель листостебельных мхов СССР. Верхоплодные мхи. [The Handbook of mosses of the USSR. The acrocarpous mosses] Л., Наука [Leningrad, Nauka], $826 \mathrm{pp}$.

SÖDERSTRÖM, L. (ed.) 1996. Preliminary distribution maps of bryophytes in Northwestern Europe.Vol.2 (Musci A-I). Mossornas Vännar,Trondheim. 69 pp.

SOLLMAN,P.1983.Notes on Pottiaceous mosses.I.- Bryologist 86: $271-272$.

SZAFRAN,B.1957.Mchy (Musci),Tom 1.- Warszawa,Polska Akad. Nauk, 1-451.

URMI, E. [\& collaborators] 1991. Rote Liste. Die gefaehrdeten und seltenen Moose der Schweiz. - Bern, EDMZ, 56.

VADAM, J.-C. 1991. Presence de Bryoerythrophyllum ferruginascens (Stirt.) Giac. en Haute-Savoie. Cryptogamie Bryol, Lichenol. 12: 73-75.

VANA, J. 1997. Bryophytes of the Czech Republic - an annotated check-list of species (1). Novit. Bot. Univ. Carol. (Praha) 11: 39-89.

ZANDER, R. H. 1978 [1979]. A synopsis of Bryoerythrophyllum and Morinia (Pottiaceae) in the New World. - Bryologist 81: 539--560. 